\title{
THE EFFECT OF COOLING RATE ON SELECTED STRUCTURAL PARAMETERS OF ADVANCED CAST NI - BASE SUPERALLOYS
}

\begin{abstract}
The $\mathrm{Ni}$ - base superalloys are used in aircraft industry for production of aero engine most stressed parts, as are turbine blades or turbine discs. The most stressing factor at $\mathrm{Ni}-$ base superalloys loading or working conditions are high temperature range of $700^{\circ} \mathrm{C}$ up to $850^{\circ} \mathrm{C}$ and, of course, centrifugal forces, and small vibrations, which produce bending of turbine blades inserted into turbine discs. All these factors cause various forms of microstructure degradation closely connected with decreasing of mechanical properties and shortening of working life as well. From this reason a dendrite arm spacing, carbides size and distribution, morphology, number and value of $\gamma^{\prime}$ - phase are very important structural characteristics for blade lifetime prediction as well as aero engine its self. In this article are used methods of quantitative metallography for evaluation of structural characteristics mentioned above on experimental materials - Ni base superalloys ŽS6K and Inconel IN 738. The high temperature effect represented here by heat treatment at $800^{\circ} \mathrm{C}$ for 10 hours, and cooling rate, here represented by three various cooling mediums as water, air, and oil, on structural characteristics and application of quantitative methods evaluation with using of SEM are presented in this paper.
\end{abstract}

Keywords: Ni-base superalloys, quantitative metallography methods, heat-treatment, cooling rate, secondary dendrite arms spacing, gamma prime evaluation, carbide evaluation

\section{Introduction}

Aerospace industry is one of the biggest consumers of advanced materials, because of its unique combination of mechanical, physical properties and chemical stability. High alloyed stainless steel, titanium alloys and nickel base superalloys are most used for aerospace applications. High alloyed stainless steel is used for shafts of aero engine turbine, titanium alloys for compressor blades and finally nickel base superalloys are used for most stressed parts of jet engine - turbine blades. Nickel base superalloys were used in various structure modifications: as cast polycrystalline, directionally solidified, single crystaled and in last years materials produced by powder metallurgy (GELL M., DUHL D.N. 1985). In this paper problems of polycrystalline nickel base superalloys turbine blades such as most stressed parts of aero jet engine will be discussed.

${ }^{1}$ Ing., PhD., University of Žilina, Faculty of Mechanical Engineering, Department of Materials Science, Univerzitná 8215/1, 01026 Žilina, Slovakia, e-mail: juraj.belan@fstroj.uniza.sk 
The structure of polycrystalline $\mathrm{Ni}$ - base superalloys, depending on a heat treatment, consist of solid solution of elements in $\mathrm{Ni}$ ( $\gamma$ - phase, also called matrix), primary carbides MC type (created by element such as $\mathrm{Cr}$ and $\mathrm{Ti}$ ), intermetallic precipitate $\mathrm{Ni}_{3}(\mathrm{Al}, \mathrm{Ti})\left(\gamma^{\prime}\right.$ - phase), and secondary carbides $\mathrm{M}_{23} \mathrm{C}_{6}$ type (created by elements such as $\mathrm{Cr}, \mathrm{Co}, \mathrm{Mo}, \mathrm{W})$. Shape and size of these structural components have a significant influence on final mechanical properties of alloy (COPLEY S.M., KEAR B.H. 1967a).

For instance the precipitate $\gamma^{\prime}$ size greater than $0.8 \mu \mathrm{m}$ significantly decreasing the creep rupture life of superalloys and also carbides size greater than $50 \mu \mathrm{m}$ is not desirable because of fatigue cracks initiation (COPLEY S.M., KEAR B.H. 1967b).

For this reason needs of new non - conventional structure parameters methods evaluation were developed. The quantitative metallography, deep etching, and colour contrast belongs to the basic methods. The quantitative metallography analysis has statistical nature. The elementary tasks of quantitative metallography are:

- Dendrite arm spacing evaluation.

- Carbide size and distribution.

- Volume ratio of evaluated phase.

- Number ratio of evaluated phase.

- Size of evaluated phase.

Application of the quantitative metallography and colour contrast on the $\mathrm{Ni}$ - base superalloys are the main objectives discussed in this paper. More detailed analysis is published in previous works (COPLEY S.M., KEAR B.H. 1967a - CHALUPOVÁ M., TILlová E., FARKAŠOVÁ M. 2014). These non - conventional methods were successfully used also for the other types of materials (SKOČOVSKÝ P., MATEJKA M. 1994 - BELAN J., SKOČOVSKÝ P. 2005).

\section{Experimental materials and methods}

The cast Ni - base superalloys ŽS6K and IN738 were used as an experimental material. Alloys contains higher amount of $\mathrm{Cr}$, they have increased gas corrosion resistance and also high creep rupture life.

These alloys were evaluated after annealing at $800^{\circ} \mathrm{C} / 10$ followed by cooling with various rate, presented with cooling in water, oil and air and compared to starting stages of alloys. The chemical composition of experimental alloys in wt \% is presented in Table 1.

Alloy ŽS6K is after casting strengthened with solid solution ( $\mathrm{Cr}$, Co and Mo), $\gamma^{\prime}$ phase $\left(\mathrm{Ni}_{3}(\mathrm{AlTi})\right)$ and with carbides $\mathrm{M}_{23} \mathrm{C}_{6}$ situated on grain boundaries. 
Table 1. Chemical composition of experimental alloys (wt.\%)

\begin{tabular}{|c|c|c|c|c|c|c|c|c|c|c|}
\hline \multirow{2}{*}{ Alloy } & \multicolumn{10}{|c|}{ Elements (wt. \%) } \\
\cline { 2 - 12 } & $\mathbf{C}$ & $\mathbf{N i}$ & $\mathbf{C o}$ & $\mathbf{F e}$ & $\mathbf{T i}$ & $\mathbf{C r}$ & $\mathbf{A l}$ & $\mathbf{W}$ & $\mathbf{M o}$ & $\mathbf{N b}$ \\
\hline \multirow{2}{*}{ ŽS6K } & $\begin{array}{c}0.13 \\
-\end{array}$ & base & $\begin{array}{c}4.0 \\
-\end{array}$ & 2.0 & $\begin{array}{c}2.5 \\
-\end{array}$ & $\begin{array}{c}9.5 \\
-\end{array}$ & $\begin{array}{c}5.0 \\
-\end{array}$ & $\begin{array}{c}4.5 \\
-\end{array}$ & $\begin{array}{c}3.5 \\
-\end{array}$ & - \\
\hline IN738 & 0.17 & base & 8.5 & - & 3.4 & 16.0 & 3.4 & 2.6 & 1.7 & 0.9 \\
\hline
\end{tabular}

Source: own study

Alloy Inconel IN 738 is produced in two modifications as a low carbon (IN 738LC) and high carbon (IN 738C). After casting it is strengthened with solid solution $(\mathrm{Cr}$, Co and $\mathrm{Mo}), \gamma^{\prime}$ phase $\left(\mathrm{Ni}_{3}(\mathrm{AlTi})\right)$ and with carbides $\mathrm{M}_{23} \mathrm{C}_{6}$ situated on grain boundaries.

For evaluation of structural characteristics the following quantitative metallography methods were used:

- Carbide distribution and average size was evaluated by software LUCIA Metalo 5.0

- Secondary dendrite arm spacing measurement;

- For number of $\gamma^{\prime}$ - phase particles coherent testing grid with area probe of square shape were used;

- For volume of $\gamma^{\prime}$ - phase particles coherent testing grid with 50 dot probes made of backslash crossing were used.

Secondary dendrite arm spacing were evaluated according to Figure 3.1. and calculated with formula (3.1.). Changing of distance between secondary dendrite arms " $d$ " is important characteristic because of base material; matrix $\gamma$, degradation via equalizing of chemical heterogeneity and also grain size growing.

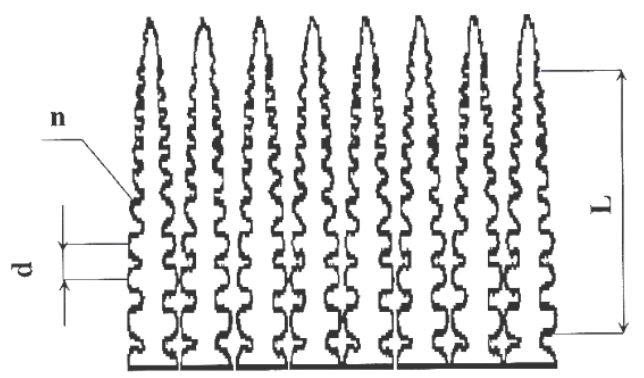

Fig. 1. Scheme for secondary dendrite arm spacing evaluation.

Source: own study 


$$
d=\frac{L}{n \times z} \times 1000 \quad(\mu m)
$$

- where "L" is a selected distance on which are secondary arms calculated (usually is chosen same value of distance as used magnification " $z$ " - reason why, is to simplify equation), " $\mathrm{n}$ " is a number of secondary dendrite arms and " $\mathrm{z}$ " is used magnification.

For evaluation of $\gamma$ and $\gamma^{\prime}$ phases were used method of coherent testing grid, number of $\gamma^{\prime}$ "N" has been evaluated by grid with 9 area probes of square shape (Figure 2a.) and volume of $\gamma^{\prime}$ "V" has been evaluated by grid with 50 dot probes (Figure.2b). After measurement was values calculated with formulas (2) and (3). For detailed description of used methods see (SKOČOVSKÝ P.,VAŠKO A. 2007, TILlOVÁ E.,PANUŠKovÁ M. 2008, TillovÁ E. et al 2011). Size of $\gamma^{\prime}$ is also important from creep rupture life point of view. Precipitate with size higher than $0.8 \mu \mathrm{m}$ can be considered as heavy degraded and cause decreasing mechanical strength at higher temperatures.

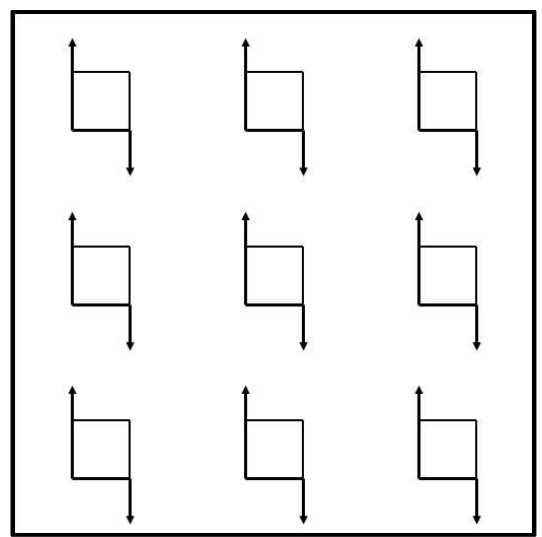

a) Number of $\gamma^{\prime}$-phase particles

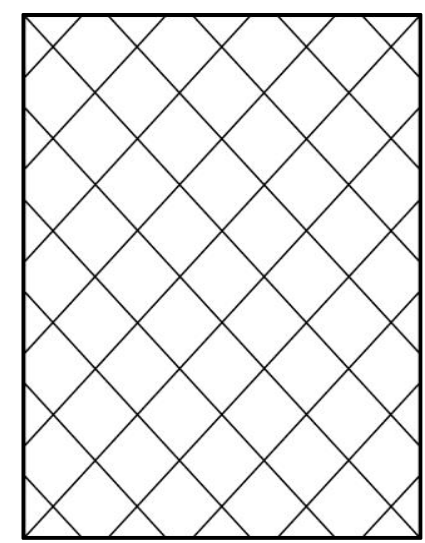

b) volume of $\gamma^{\prime}$-phase particlces

Fig. 2. Coherent testing grid for $\gamma^{\prime}$-phase evaluation.

Source: own study

$$
N=1.11 \times z^{2} \times x_{\text {med. }} \times 10^{-9}(\mu m)
$$

- where "N" is a number of $\gamma^{\prime}$ particles, " $z$ " is used magnification, " $\mathrm{x}_{\text {med." is }}$ medium value of $\gamma^{\prime}$ - phase measurements.

$$
V=\frac{n_{S}}{n} \times 100
$$


- where "V" is a volume of $\gamma^{\prime}$ particles, " $\mathrm{n}_{\mathrm{s}}$ " is medium value of $\gamma^{\prime}$ - phase measurement and " $\mathrm{n}$ " is a number of dot probes (when used testing grid with 50 dot probes equation become more simply: $\mathrm{V}=2 \mathrm{n}_{\mathrm{s}}$ ).

\section{Experimental results and discussion}

The microstructure of starting stage is created by carbides in chain morphology situated on grain boundary and large amount of eutectic cells $\gamma / \gamma^{\prime}$ (Fig. 3a. for ŽS6K alloy and Fig. .3b. for IN738 alloy). An example of microstructure after annealing at $800^{\circ} \mathrm{C} / 10$ hrs., focused on carbide distribution is presented in Fig. 4.

a)

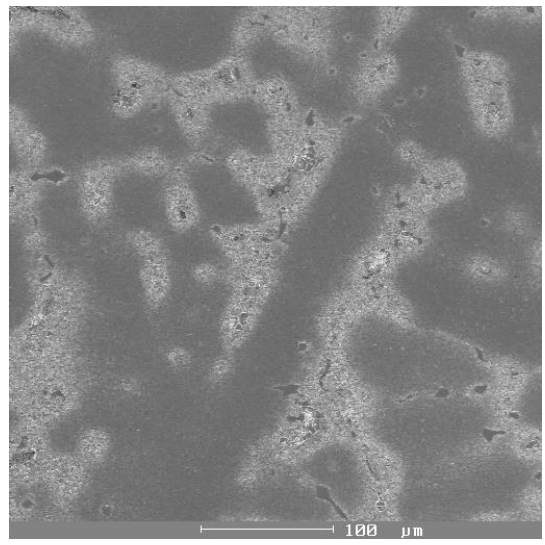

b)

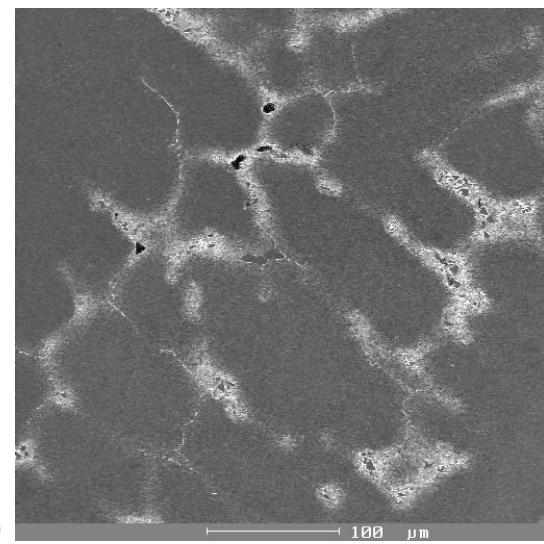

Fig. 3. The micrographs of starting stages for: a) ŽS6K alloy, and b) IN738 alloy, SEM.

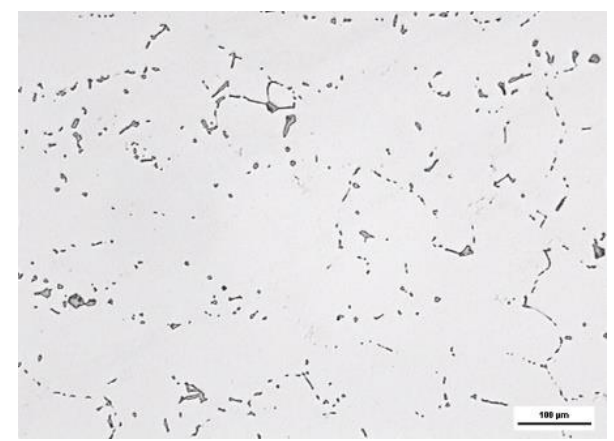

a)

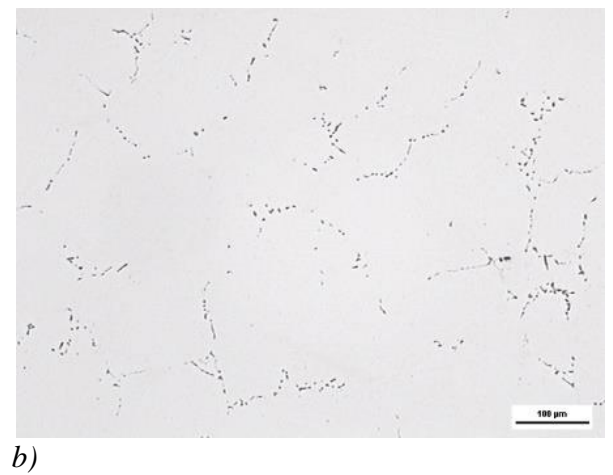

b)

Fig. 4. The micrographs after $800^{\circ} \mathrm{C} / 10 \mathrm{hrs}$. for carbide evaluation: a) ŽS6K alloy, and b) N738 alloy.

Source: own study 
After $800^{\circ} \mathrm{C} / 10 \mathrm{hrs}$. the microstructure shows some changes, mainly in number of carbides, its distribution and size. This effect is forced by diffusion mechanism and cooling rate when quick cooling represented by water gives not sufficient time for carbide growth. The results of carbide evaluation are presented in Fig. 3.5.

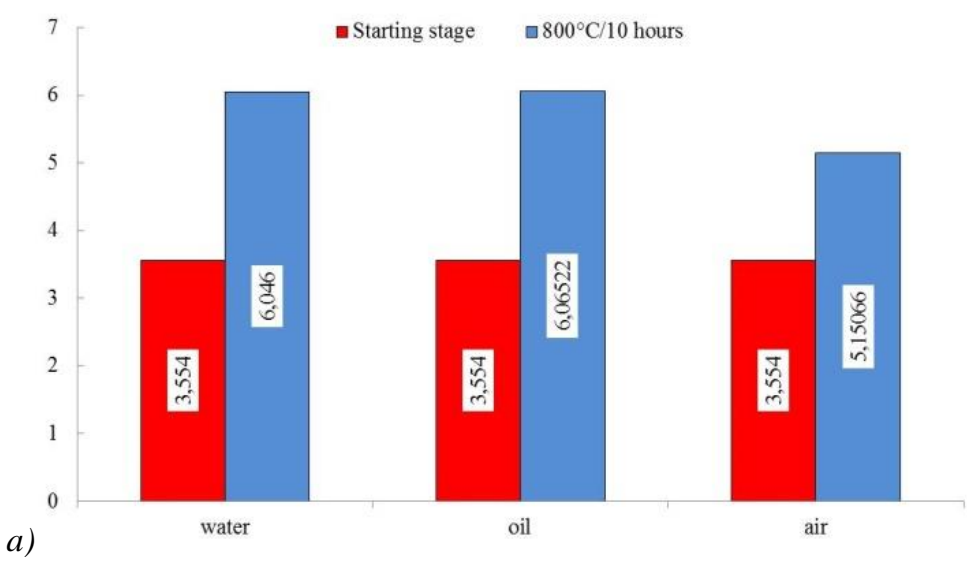

a)

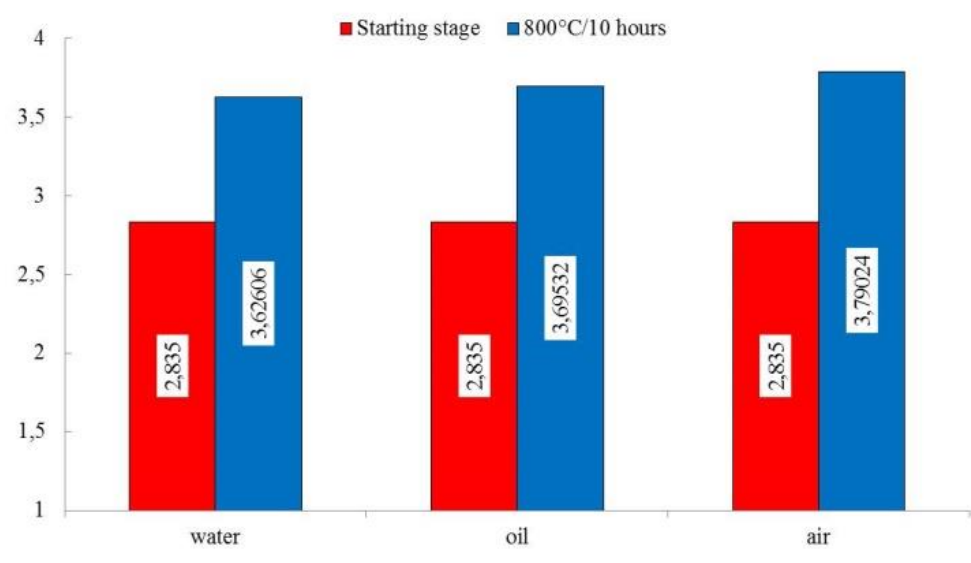

Fig. 5. Results for carbide size ( $\mu m$ ) evaluation for: a) ŽS6K, and b) IN738.

Source: own study

For dendrite structure evaluation method of measuring secondary dendrite arm spacing was used. The results of measuring are presented in Table 2. The cast materials are characterized by dendritic structure, as can be seen in Fig. 3a and 3b, which is a chemical heterogeneity result. Increase of annealing time decreases its chemical heterogeneity. It means that the secondary dendrite arm spacing is increased (the dendrites are growing). ŽS6K dendrite arm spacing is increased in dependence of 
the annealing time, annealing temperature and cooling medium from 126.58 to $138.89 \mu \mathrm{m}$.For ŽS6K alloy it means secondary dendrite arm spacing increasing about $8 \%$ depending on cooling medium. The Inconel IN 738 dendrite arm spacing is increased in dependence of the annealing time, annealing temperature and cooling medium from 142.86 to $172.41 \mu \mathrm{m}$. For IN738 alloy it means secondary dendrite arm spacing increasing about $20.7 \%$ depending on cooling medium.

Table 2. Results for secondary dendrite arm spacing measurement ( $\mu \mathrm{m})$

\begin{tabular}{|c|c|c|c|c|}
\hline Alloy & $\begin{array}{c}\text { Starting } \\
\text { stage }\end{array}$ & $\begin{array}{c}\text { Cooling on } \\
\text { water }\end{array}$ & $\begin{array}{c}\text { Cooling on } \\
\text { oil }\end{array}$ & $\begin{array}{c}\text { Cooling on } \\
\text { air }\end{array}$ \\
\hline ŽS6K & 185.19 & 126.58 & 131.58 & 138.89 \\
\hline IN738 & 161.29 & 142.86 & 156.25 & 172.41 \\
\hline
\end{tabular}

Source: own study

The characteristics of $\gamma^{\prime}$ - phase morphology were also measured using the coherent testing grid methods. As were mentioned above, the number and volume of $\gamma^{\prime}$ - phase have significant influence on mechanical properties of this alloy, especially on creep rupture life. Average satisfactory size of $\gamma^{\prime}$ - phase is about $0.35-0.45 \mu \mathrm{m}$ and also carbide size should not exceed size of $5 \mu \mathrm{m}$ - because of fatigue crack initiation (DONACHIE M.J., DONACHIE S.J. 2002). Another risk of using high temperature loading or annealing is creation of TCP phases, such $\sigma$ - phase or Laves phase, in range of temperature $750^{\circ} \mathrm{C}-800^{\circ} \mathrm{C}$. Results for $\gamma^{\prime}$-phase evaluation are presented in Table 3.

Exposing for 10 hours at annealing temperature the volume of $\gamma^{\prime}$ - phase was increased. Of course, various cooling mediums have different influence on $\gamma^{\prime}$-phase characteristics. The most significant increasing in volume of $\gamma^{\prime}$-phase has been observed at ŽS6K alloy where its volume increased from $39.4 \%$ to $72.4 \%$ what means increasing about $83.7 \%$ (Figs. 6a and 6b) compared to starting stage. The IN738 alloy does not show such increasing. Also here th $\gamma^{\prime}$-phase increases its volume from $60.4 \%$ to $66.6 \%$. It is not such dramatic increasing, only for $10.26 \%$, compared to starting stage (Figs. 6c and 6d).

Vickers hardness measuring was carried out to confirm possible carbide redistribution and decreasing of the chemical heterogeneity. It was found that the main influence on the hardness variation has cooling medium, as we can see from results presented in Table 3.3. The highest hardness was reached after cooling on air, after 10 hours -489.7 HV10 (for ŽS6K alloy) and 410 HV10 (for IN738 alloy). From the result it is clear that holding time at temperature of annealing has no so significant 
Zeszyty Naukowe

No 1(6) 2017

Quality. Production. Improvement

s. $20-30$

effect on hardness value, but the cooling rate represented by various cooling medium has significant influence on the hardness.

Table 3. Results for $\gamma^{\prime}$-phase evaluation

\begin{tabular}{|c|c|c|c|c|}
\hline Alloy & $\begin{array}{c}\text { Number of } \\
\gamma^{\prime}-\text { phase } \\
N\left[\mu \mathrm{m}^{-2}\right] \\
\end{array}$ & $\begin{array}{c}\text { Volume of } \\
\gamma^{\prime}-\text { phase } \\
V[\%] \\
\end{array}$ & $\begin{array}{c}\text { Size of } \\
\gamma^{\prime}-\text { phase } \\
u[\mu \mathrm{m}]\end{array}$ & $\begin{array}{c}\text { Hardness } \\
\text { [HV 10] }\end{array}$ \\
\hline ŽS6Ks & 2.47 & 39.4 & 0.61 & 403 \\
\hline ŽS6KWater & 1.95 & 56.2 & 0.54 & 456.7 \\
\hline ŽS6KOil & 1.60 & 63 & 0.63 & 476.3 \\
\hline ŽS6K & 1.50 & 72.4 & 0.69 & 489.7 \\
\hline IN738s & 1.68 & 60.4 & 0.76 & 393.4 \\
\hline IN738 Water & 2.14 & 58.4 & 0.52 & 374 \\
\hline IN738Oil & 1.84 & 63.6 & 0.59 & 394 \\
\hline IN738 $_{\text {Air }}$ & 1.63 & 66.6 & 0.64 & 410 \\
\hline
\end{tabular}

Source: own study

a)

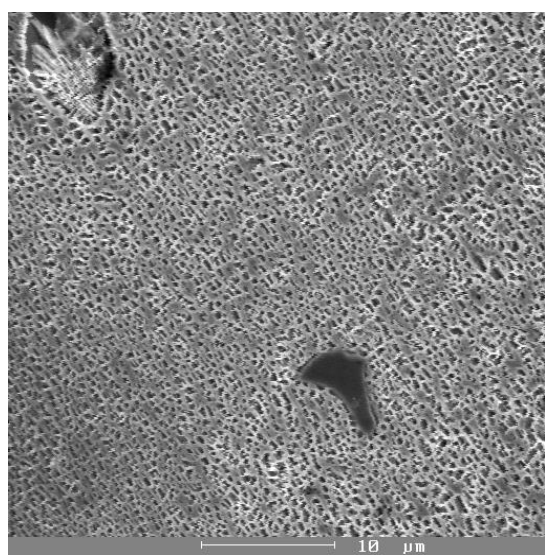

b)

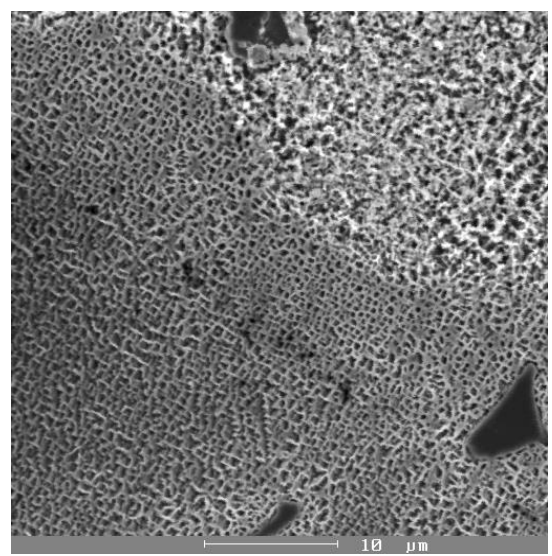


c)

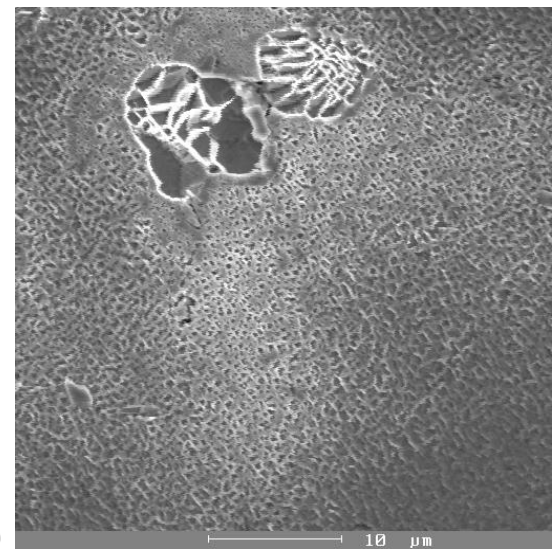

d)

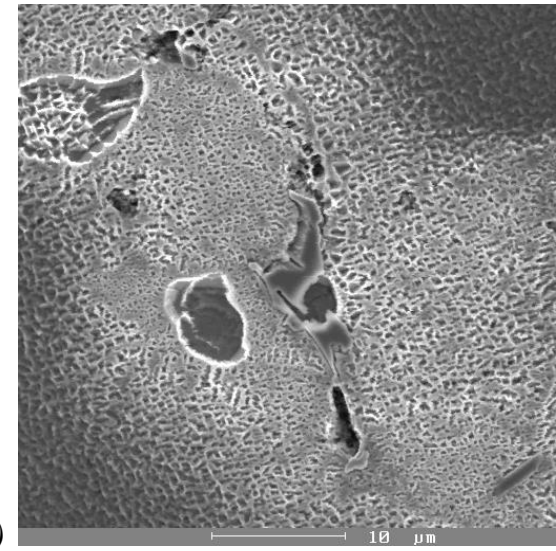

Fig. 6. Micrographs for $\gamma^{\prime}$-phase evaluation: a) starting stage, b) after $800^{\circ} \mathrm{C} / 10 \mathrm{hrs}$ cooling on air of ŽS6K alloy; c) starting stage, and d) after $800^{\circ} \mathrm{C} / 10 \mathrm{hrs}$. cooling on air of IN738 alloy, SEM.

Source: own study

\section{Conclusions}

As cast $\mathrm{Ni}$ - base superalloys ŽS6K and IN738 were used as an experimental material. The structural characteristics were evaluated from starting stage of sample and after annealing at $800^{\circ} \mathrm{C} / 10 \mathrm{hrs}$. with using of quantitative metallography methods. The results are as follows:

- Structure of the samples is characterized by dendritic segregation. In dendritic areas fine $\gamma^{\prime}$ - phase is segregate. In interdendritic areas eutectic cells $\gamma / \gamma^{\prime}$ and carbides are segregated.

- Holding time (10 hrs.) does have significant influence on the carbide particles size. The size of carbides is under critical level for fatigue crack initiation only in starting stage for ŽS6K alloy. After applied annealing the carbide size increases over $5 \mu \mathrm{m}$ what may act as fatigue crack initiation sites. Carbide size at IN738 alloy is under set $5 \mu \mathrm{m}$ value. The increase rate of cooling has significant effect on the carbide particles ratio.

- Chemical heterogeneity of the samples with longer holding time is decreasing. It is reason of sufficient time for diffusion mechanism, which is confirmed by secondary dendrite arm spacing measurement results.

- The volume of $\gamma^{\prime}$ - phase with longer holding time is increasing and also $\gamma^{\prime}$ - phase size is growing. With higher rate of cooling are $\gamma^{\prime}$ particles finer. 
- There was no evidence of TCP phase presence even though high annealing temperature.

- Cooling rate has also influence on the hardness. At lower rate of cooling the internal stresses are relaxed, which caused hardness increase - changing of the dislocation structure.

Cooling rates, represented by various cooling mediums have influence on diffusion processes in structure of alloys. These diffusion processes are the main mechanism for segregation and creating of carbide particles, equalization of chemical heterogeneity, $\gamma^{\prime}$ - phase segregation and are responsible for structure degradation of these alloys as well.

\section{Acknowledgments}

The project presented in this article is supported by Scientific Grant Agency of Ministry of Education of The Slovak Republic and the Slovak Academy of Sciences, No. 1/0533/15 and No. 049ŽU-4/2017.

\section{Bibliography}

1. COPLEY S.M., KEAR B.H. 1967. Structural characteristics of superalloys, part I. „The Minerals, Metals \& Materials Society - The American Institute of Mining, Metallurgical, and Petroleum Engineers" 239, pp. 977-983.

2. COPLEY S.M., KeAR B.H. 1967. Structural characteristics of superalloys, part II. „The Minerals, Metals \& Materials Society - The American Institute of Mining, Metallurgical, and Petroleum Engineers" 239, pp. 984-989.

3. DonachiE M.J., DonachIE S.J. 2002. Superalloys - A technical Guide. ASM International. USA.

4. LEVERANT G.R., KEAR B.H. 1970. Mechanical properties of advanced superalloys. „Metallurgical and Materials Transactions” 1, pp. 491-498.

5. JACKSON J.J. 1977. Evaluation of superalloys structural characteristics. „Metallurgical and Materials Transactions" 8A(10), pp. 1615-1620.

6. Gell M., Duhl D.N. 1985. Progressive technologies in superalloys. „Advanced high temperature alloys" ASM. USA.

7. Chalupová M., Tillová E., FARKaŠOvÁ M. 2014. Microstructure analysis of AlSi10MgMn aluminium cast alloy. "Materials Science Forum" 782, pp. 365-368.

8. SKOČOvSKÝ P., MATEJKA M. 1994. Cast iron microstructure - metallography handbook. EDISŽU Žilina (in Slovak).

9. SKOČOVSKÝ P., VAŠKO A. 2007. The quantitative evaluation of cast iron structure $1^{\text {st }}$ Edition. EDIS, Žilina. (in Slovak). 
10. Belan J., SKoČOVSKÝ P. 2005. The quantitative metallography of $\mathrm{Ni}$ - base superalloys.,XX MIEDZYNARODOWE SYMPOZJUM, Metody oceny struktury oraz własności materialow i wyrobów", pp. 83-88.

11. Tillová E., PanušKová M. 2008. Effect of Solution Treatment on Intermetallic Phase's Morphology in AlSi9Cu3 Cast Alloy. "Mettalurgija" 47, pp. 133-137.

12. Tillová E., Chalupová M., Hurtalová L., Bonek M., Dobrzanski L. A. 2011. Structural analysis of heat treated automotive cast alloy. "Journal of Achievements in Materials and Manufacturing Engineering” 47, pp. 19-25. 